\title{
Unravelling the Body/Mind Reverberations of Secrets Woven into Charlotte Brontë's Villette
}

\section{Francisco José Cortés Vieco}

The pervasive psychological realism of Charlotte Brontë's Villette (1853) challenges scholarly assumptions based on her biography or her indoctrination to Victorian medical discourses, as it explores dysfunctional body/mind interrelations, particularly those evidencing patriarchal pressures and prejudices against women. Under the guise of her heroine Lucy, the author becomes both the physician and the patient suffering from a female malady of unnamed origin. This article intends to prove that, instead of narratively unravelling her creature's past trauma with healing purposes, the author conceals its nature to protect her intimacy and she focuses on the periphery of her crisis aftermath to demonstrate its severity by means of the psychosomatic disorders that persistently haunt her life: depression, anorexia nervosa and suicidal behavior. Brontë's literary guerrilla of secrecy aims, simultaneously, to veil and unveil the core of Lucy's clinical case with an unequivocal diagnosis: a harmful, mysterious event from her childhood/adolescence, whose reverberations repeatedly erupt during her adulthood and endanger her survival. Unreliable but "lucid", this heroine becomes the daguerreotype of her creator to portray life as a sad, exhausting journey, where professional self-realisation - not love or marriage - turns into the ultimate recovery therapy from past ordeals, never successfully confirmed in the case of Lucy, who epitomises a paradigm offemininity in Victorian England: the impoverished, solitary, middle-class woman.

\section{Keywords}

Body; mind; woman; trauma; sequelae; anorexia; suicide; recovery

I tell my secret? No indeed, not I: Perhaps some day, who knows? But not to-day; it froze, and blows, and snows, And you are too curious: fie! You want to hear it? Well: 
Only, my secret's mine, and I won't tell.

(Christina Rossetti)

Beneath the childlike, naïve puns, this stanza may conceal the unspeakable constituent of the female experience in Victorian literature. Dressed with silence, euphemisms or wit, painful events in women's lives have been traditionally placed outside the universe of acceptable language and its socially-validated reality. However, some $19^{\text {th }}$-century novels timidly unravel their anxieties and sorrows, confessed by first-person voices disguised by the symptomatology of psychosomatic disorders, which pervade their narratives. These revelations suggest that mental processes and nervous breakdowns affect the body, whose ailments often lack organic, physical causes.

The epistemology of the Cartesian body/mind dualism has insisted upon the primacy of analytic thought over biological phenomena throughout Western history. In transit to its aesthetic subversion in modern times, Victorian Realism is a literary movement, wherein social and public dimensions prevail to the detriment of other spheres. Yet, this genre also reflects a favourable climate to scrutinise the interactions between soma and psyche, emotions and reason, because the long-lasting romance between science and art enables the former to shape the artefacts of the latter. In Idioms of Distress, Lilian Furst reviews the body/mind continuum in the diagnosis and prognosis of illnesses from Hippocrates until the $19^{\text {th }}$ century. At that particular time, doctors believed that states of mind, conditioned by multifarious physical factors and social determinants, could worsen or ameliorate diseases. Furst also defines such ailments as "translations or conversions", which dramatise the displacement of mental distress or conflicts through the human organism (6). Stemming from emotional anguish and resulting in physical maladies, psychosomatic disorders include hypertension, respiratory problems, gastrointestinal disturbances, migraine, tension headaches, sexual dysfunctions and dermatitis (Tofighi 124). Generally speaking, they are considered to be "borderline conditions", liminally located between neurosis and psychosis regardless of Freudian postulates $^{1}$ (Kradin 46). Athena Vrettos analyses the equivocal condition of neurosis in Victorian medical research and praxis, in terms of its duality between its physical and mental disturbances. It had vague symptoms that did not correspond to organic etiologies, like cancer or tuberculosis (553). Nevertheless, its nervous manifestations did not lead to madness, and the sufferers could continue to function rationally, despite frequent acute episodes where their nerves were most sensitised (Vrettos 553). Once this body/mind 
tandem was institutionalised as pathogenic by the $19^{\text {th }}$-century medicine and patriarchal order, contemporary artists were tempted to transcribe physicality into words, or even to "palpate" illnesses in their works.

To intrude on the Victorian literary Establishment, an embryonic subculture of English women writers confronted or, perhaps, contributed to the perpetuation of misogynist gender prejudices which predominated in social and medical discourses. Together, public and clinical worlds inexorably associated mental breakdown to the female body. $19^{\text {th }}$-century psychiatry even formulated theories of women's insanity based on the experience of the biological crises of menstruation and life-cycle during which their minds were weakened (Showalter $55^{-56}$ ). To delve into this ideological distortion that intertwines the nervous and reproductive systems, Foucault argues that science has defined sexuality as a domain susceptible to pathologies, calling for normalising intervention (68). Women's bodies were often "hysterized" and became the target of male physicians' efforts, because they were thought to be "saturated with sexuality" (104). Stigmatised as "redundant, odd or superfluous", unmarried middle-class ladies were also considered a social problem in Victorian England ${ }^{2}$ (Showalter 61). Deprived of an occupation outside domesticity and coerced to define themselves only through personal relationships, such unwed women were forced to depend on their inner lives and were thought to be more prone to depression and lunacy (Showalter 64).

At first sight, Charlotte Brontë's last novel Villette (1853) is her own literary therapy to alleviate the shock of bereavement provoked by the deaths of her sisters: Emily and Anne ${ }^{3}$. Readers and critics traditionally unlock the inexpressible mysteries of this fiction with the key of autobiography (Carlisle 263). In any case, this work symbolises her depleted self-confidence as a writer after the collapse of the fertile intellectual haven inhabited by their unique sororal understanding in her native Yorkshire. Furthermore, unrequited love, isolation, poverty, thwarted professional aspirations, infirmity and early death circumscribe Brontë's life experience to that of tragedy. Social constraints or heredity also might have been the precursors of her self-diagnosis of mental morbidity. In fact, Vrettos argues that the author was exposed to the prevailing theories of neurosis through consultations about her own nervous symptoms (56o). Possibly to document the metaphor of forlornness for her future novel, Brontë visited prisons and asylums to witness the sequelae of the method "solitary confinement", e.g., nightmares, hallucinations and suicide attempts (Showalter 69). Such personal encounters could demonstrate the influence of contemporary science on her writings, as a patriarchal indoctrination that 
turned femininity into a pathology and had a key impact on $19^{\text {th }}$-century literature beyond Brontë's example4.

This article intends to illustrate how the author simultaneously transfigures herself into a therapist (as a narrator) and a sufferer (as a heroine) of psychosomatic disorders in Villette. Within this autobiographical context, the novel is not only a tribute to human pain, but its protagonist - Lucy Snowe also becomes the psychological daguerreotype of an older, defeated Charlotte Brontë, once the self-portrait of romantic passion and youth in her bestseller Fane Eyre (1847) would have vanished. In a more mature Villette, the novelist already understands life as the exhausting, sad journey for her creature, whose happiness is always postponed to an uncertain future. Anticipating her body/mind disturbances due to buried memories and past ordeals with subsequent eruptive replicas of emotional damage, her mental nebula collides with a harsh reality and unsympathetic people. In fact, her status quo reflects the divorce between middle-class women and the patriarchal pillars of family, religion, society and nation during the $19^{\text {th }}$ century. I will focus, firstly, on Lucy's determination to veil an innominate trauma. Secondly, I will diagnose proven psychosomatic symptoms of her persistent malaise, including delirium, reclusion, anorexia nervosa, sexual anxiety or suicidal behaviour. And thirdly, I will explore the prognosis of her tentative recovery, tinged with the narrative "tranquillity" of her retrospective look to the past from an older age. With such purposes, seminal literature on trauma studies and post-traumatic stress disorders are being used to contextualise and analyse Villette.

According to this article's approach, physical degradation and nervous collapse are the vital sources of inspiration for Charlotte Brontë's psychological realism in the novel. The author's intended access to the female body/mind, paradoxically, bestows the narrative authority upon the consciousness of her wretched, unreliable heroine, in defiance of sentimental expectations from mainstream criticism and readers, who enhance the author's mournfulness as a sad but logical consequence of the deaths of her beloved sisters. Lucy never unravels the origin or nature of her torturing, unknown ordeal, which occurred prior to the narrative onset. From an old age, she recalls an episode from her adolescence at her godmother's house - Mrs. Bretton -, which precedes eight years of silence: "buried [...] in a long prayer" $(V 35)^{5}$. From this in medias res prelude, she never refers to her family, home or remembrances from that period. Her existence and identity prior to this painful experience seem to be irrevocably destroyed. Moreover, this unexplored, harrowing event from the past threatens and conditions the whole novel. Because it cannot 
be pronounced nor confronted in Villette, ellipsis becomes its fundamental literary device. Consequently, Brontë encodes her writing in such a way that the reader can only perceive the aftermath of Lucy's drama, plagued with psychosomatic disorders, like nervous deterioration, anorexia nervosa and masked suicide attempts. She uses the trope of paralepsis ${ }^{6}$ to deliberately omit the novel's interpretative core. Albeit she is stubbornly reluctant to articulate her personal disaster, such a literary tactic does confirm its occurrence and transcendence in the heroine's life by, simultaneously, undressing and veiling this event in her memoirs. Only thanks to relapsing nightmares of water, a menacing sea-storm of physical danger, does the reader decipher that she survived a metaphorical shipwreck:

I must somehow have fallen over-board, or that there must have been wreck [...] I too well remember a time - a long time, of cold, of danger, of contention $[. .$.$] When I have the nightmare, it repeats the rush and saltness$ of briny waves in my throat, and their icy pressure on my lungs. I even know there was a storm [...]. For many days and nights neither sun nor stars appeared, we cast with our own hands the tackling out of the ship; a heavy tempest lay on us; all hope that we should be saved was taken away $[\ldots]$ The ship was lost, the crew perished. (V 35)

Critics traditionally solve this textual enigma by turning to the author's (auto)biography. However, Brontë's constant recall of her past happy-life with her sisters contrasts with Lucy's deliberate recollection of pending oblivion. This possibly evidences an unnamed taboo, like sexual/psychological abuses during her childhood or adolescence. In fact, mental ordeals of that sort can produce repressed memories converted into somatic symptoms (Kradin 39). A haunting remark of the heroine after having been forced to leave her godmother and return home, could detect the fear of meeting again a dysfunctional, negligent family: "It will be conjectured that I was of course glad to return to the bosom of my kindred. Well! The amiable conjecture does no harm, and may therefore be safely left uncontradicted" (V 35). Even her stay at the Brettons could have been aimed at preserving her from the hostility at the Snowes' (Haller 150). Cathy Caruth coins the definition of trauma as the direct, immediate brush with death, or the experience of surviving that near fatal disaster, and yet being forced to relive it repeatedly in dreams and lacerating memories, because both are unbearable: the nature of the event and that of its survival (7). Judith Herman refers to this same concept as the 
affliction of the powerless, being the victim rendered helpless by a strong force (33). The reasons causing this situation are extraordinary, not because they occur rarely, but because they overwhelm the ordinary adaptations to life and involve threats to bodily integrity (Herman 33). These explanations of trauma help construe Lucy's nightmare of the terrifying immediacy of violence and death: sinking, drowning and yet being eventually rescued. They also suggest her unyielding refusal to understand the event that causes her so much continuing damage. In fact, this sequel insinuates her voluntary amnesia or blunt denial of avowal. In line with this assumption, Janice Carlisle argues that Villette is a carapace of defences against the intolerable pain of memory and the transgression of Victorian autobiographical conventions, when the novelist avoids the emotional cost of retrospection in her heroine's account from older years $\left(265^{-266)}\right.$.

Brontë's last novel is the chronicle of Lucy's peripatetic experiences during one year and a half. She selectively erases the narrative clues of a previous dreadful event which, in turn, regresses from her unconsciousness through the psychological beating of grievous flashbacks, self-destruction, isolation, Gothic hallucinations and fasting, without literary adornments. Although she struggles to dodge the lethal psychophysical threat that persecutes her, the novel mirrors its reverberations to build an in-depth picture of female subjectivity. According to Caruth, trauma is not locatable in the simple violent or original event from an individual's past, but rather in the way that its very unassimilated nature - the way it was precisely not known in the first instance - returns to haunt the survivor later on in nightmares (4). Besides, Vrettos states that the metaphors of tempests and oceans in Villette both express and provoke its heroine's hysteria, merging imaginative and corporeal experiences $(564)$. Thanks to water imagery that invades Lucy's throat and lungs, the wrath of sea also shrouds a sinking boat - symbolically herself - that surrenders because it is too far away from "human" coasts. If the reader now discarded the interpretation of the heroine's shipwreck as a failed self-destructive attempt, he/she could surely connect the clinical evidence of her emotional turmoil with her unreliability as the narrator of her own life. However, her distress productively opens wide her mind for literary purposes, not to deliver an irrefutable diagnosis that would jeopardise the author's intended strategy of secrecy, but to detect body/mind symptoms of Lucy's painful, past experience, as well as to make a prognosis of its plausible reverberations: psychosomatic or post-traumatic stress disorders. Psychiatrists like Judith Herman have identified the three main sequelae of trauma: first, 
intrusion or when this harrowing past event is continually recurring in the victim's present and interrupts her normal course of life; second, constriction or when she feels powerless and surrenders to a numbing state or paralysis; and third, hyperarousal or the persistent expectation of danger (35). The latter's alertness, marked by panic or rapid heartbeat, is explained by the alreadymentioned dreams of physical threat, but this is not the only affliction found in the heroine's clinical case.

Brontë portrays Lucy as a twenty-three-year-old woman, already called a "spinster". She belongs to the middle-class, but she is a poor, solitary vagabond, without beauty, family or connections, a present home or a past. The chapter of her life as the lady companion of an invalid elderly woman, whose fiancé died before their wedding years before, becomes an oracle for her. It foreshadows that, in the future, she will embrace the same stigmatised caste of the old maids, to be later confirmed by the novel's denouement. Lucy wanders in a state of hibernation, where only the comatose sensations of inactivity are pleasurable to her: "My homeless, anchorless, unsupported mind had again leisure for a brief repose $[. .$.$] no further action will be required of$ me" $\left(V_{51}\right)$. Her musings connect her psychological distress with her physical atrophy, which would demonstrate the psychosomatic disorder of constriction. In fact, Brontë's psychology of the body does not alleviate her heroine's emotional damage, but it rather anticipates that her soma symptomatically articulates the suffering of her psyche, when linguistic explanations fail to exteriorise her mental confusion. After the rich woman whom Lucy looks after dies, her professional situation quickly deteriorates. She becomes a destitute wanderer, a foreigner in her own body and country. Without physical forces, but having nothing to lose with this decision, she initiates a secular pilgrimage when she abandons England to go to work to Villette ${ }^{7}$. However, she keeps her despondency as her only - but ferocious - partner during the voyage: "the secret but ceaseless consciousness of anxiety lying in wait on enjoyment, like a tiger crouched in a jungle" (V 61). Lucy's somatic reaction underneath this feline metaphor is the corporeal threat, namely the disorder of hyperarousal, that provokes her adrenalin rush and unpleasant excitation. In turn, it neutralises the resistance of her immune system against a psychological defeat. In spite of this, she keeps her mental faculties "lucid", when she sensibly acknowledges that she must find strength to endure misfortune, because her current circumstances of economic dependence and homelessness force her to find an employment: "I was born only to work for a piece of bread, to await the pains of death" ( $V$ 229). Albeit this textual glimpse of rational thought, 
her mental equilibrium is endangered by the reckless attitude of not being afraid of death: "I was inured to suffering: death itself had not [...] those terrors for me which it has for the softy reared" $\left(V_{50}\right)$. In fact, this excerpt proves intrusion, or the most dangerous stress disorder, because of the negative impact of the past trauma on the safe course of her life and on her debilitated sense of self-preservation.

While Lucy is journeying to her new destination, she confesses: "my fondness of a sea-voyage had yet to undergo the test of the experience" ( $V$ 53). This seemingly irrelevant declaration undermines the hypothesis that the shipwreck from her nightmares truly occurred at a younger age. Therefore, it should be rather understood as a metaphor of trauma, according to Caruth's symbolic definition. Upon her arrival in Villette, the heroine is equally aimless and hopeless. Her dilemma between fighting for life or surrendering to death persists: "About the present, it was better to be stoical: about the future... to be dead. And in a catalepsy and a dead trance [...] I was roused and obliged to live" (V 109). She eventually obtains a job as a nanny and, later, as an English teacher at Madame Beck's boarding school for girls, but there she will not interact with her students and colleagues. Sunken in an exhausting physical and mental hyperactivity, the core of the novel reflects how Lucy avoids apprehending the sensorial world and living new experiences with physical intensity, so as to defer her confrontation with the painful, past event, that could be recalled if she abandoned her chosen state of emotional dormancy. In fact, Brontë turns her heroine into a passive narrator/spectator with a mere supporting role in her own autobiography. Again, her authorial guerrilla of ellipsis aims to conceal Lucy's true self from the public, because its disclosure could degenerate into the social stigmatisation of this sufferer, linked to its cause: the unutterable trauma. Due to Brontë's use of paralepsis, readers are distracted by the narration of incidents and digressions indirectly related to her heroine, because they rather concern the lives of other characters from Villette. Although they are mostly overlooked by her new acquaintances, her body/mind disorders are also surreptitiously destined to provoke our attention. In this continental city, she avoids human touch and interiorises the humiliations perpetrated by her pupils, due to her odd personality, English origins and equivocal social class ${ }^{8}$. The best illustration comes from her spoiled pupil Ginevra. Her curiosity seeks to unveil the mystery of her teacher: "I suppose you are nobody's daughter [...] you have no relations; you can't call yourself young at twenty-three. You have... no beauty. As to admirers, you hardly know what they are $[. .$.$] I believe you never were in love, and never$ 
will be $[\ldots]$ though you might have your own heart broken, no living heart will you ever break" ( $V$ 146). This cruel, unsympathetic behaviour ignores the evidences of the latent trauma in Lucy's secret life, because Ginevra superficially explores her identity only guided by proven cues: age, class and beauty. Her deliberate aloofness to harm a weak rival - older, destitute and plain - and to assert her superiority - genetic and public - succeeds in tearing up the heroine's already pierced self-esteem.

Villette opposes the healthy appetite of Lucy's robust pupils at Madame Beck's school to her persistent avoidance of meals for days. Its harmful consequence, anorexia nervosa ${ }^{9}$, would therefore her main psychosomatic disorder, because it is deeply related to her emotional upheavals. Diagnosed only to women by $19^{\text {th }}$-century medicine, Helen Malson argues that it was associated to hypochondria and hysteria (59). Whereas the former provided the historical and etymological relationship between nervous and gastric disorders, the latter epitomised the gendering of nerves and the patriarchal construction of women as being pathologically nervous and inferior (Malson 59-6o). In Lucy, this condition is detected by the ambivalent alternation between fasting periods, when she only ingests some bread and tea, and days when sudden hunger sensations replenish her brain, but they are hardly satisfied, or only satiated by the compulsive consumption of sweets. The longing for this food proves her need for affection (Krugovoy-Silver 100). Anorexia may also dramatise her psychological wound ${ }^{10}$, because according to Malson, sexual abuse, dysfunctional families or past martyrdoms may be precursors of this ailment (85). By means of a gastric emptying, Lucy metabolises the painful trauma aftermath, but thanks to this malady, Brontë also problematises the gender repression enforced on thin bodies by the Victorian patriarchy ${ }^{11}$. In fact, $19^{\text {th }}$-century societies linked food with femininity to promote restrictive eating habits among middle-class girls. They valorised physical frailty as a sign of their spiritual vocation, the weightless mind, in detriment of the sexual temptations of heavy anatomies. Likewise, the act of eating was considered to be a male privilege, whereas starvation insinuated female powerlessness (Krugovoy-Silver 102). Some women confused this oppressive praxis of food restriction, because they understood that fasting also enabled the purification of their body. By vacating any "sinful", organic nutrients from it, they could even cultivate a mental and intellectual life, even a literary vocation like Charlotte Brontë. Moreover, these consumptive girls became an icon of female beauty for Victorian male artists, like Edgar Allan Poe or the Pre-Raphaelites. In contrast, Villette could rather insinuate that 
anorexia nervosa may drive its sufferers to self-destructive options, because torturing the body implies eradicating its carnality and, therefore, its vital signs. In fact, emaciation and voluntary death alike are the irretrievable aggressions of the psyche against the soma, which are often found together in the same clinical cases. Experts conclude that a suicidal person undergoes a "bodily dissociation", or the estrangement between the self and its anatomy (Orbach 195). Although they are only one, the mind detaches itself and it psychologically experiences the suffering body as if it were the "other" (Kradin 51). As a result, there is a negative attitude that neglects the latter, possibly leading to suicide (Orbach 195). Lucy's isolation and her rejection to share meals with hostile people around her exteriorise this same intestinal war of violence, not targeted against others, but headed by her empowered mind to punish her frail, thin body, which she understands as alien and repulsive.

A vacation spent alone at the school worsens the heroine's body/mind disorders: "I hardly knew how I was to live to the end. My spirits had long been gradually sinking; now [...] they went down fast [...] My nervous system could hardly support what it had for many days and nights to undergo in that huge, empty house" (V156). Brontë had not previously masked Lucy's desires of death that would now materialise as a thwarted suicide attempt. Creator and creature, however, would conceal its minute account. During one rainy night, they could narratively collaborate to obscure self-destruction, thanks to a textual symptomatology of a non-specified mental sickness and an overdose of insomnia, oneiric obsessions, delirium and an enigmatic lethal liquid:

An avenging dream [...] remained scarce fifteen minutes - a brief space; but sufficing to wring my whole frame with unknown anguish; to confer a nameless experience that had the hue, the mien, the terror, the very tone of a visitation from eternity [...] A cup was forced to my lips, black, strong, strange, drawn from no well, but filled up seething from a bottomless and boundless sea. Suffering, brewed in temporal or calculable measure, and mixed for mortal lips, tastes not as this suffering tasted. Having drank and woke - as consciousness returned - ready to cry out on some fellowcreature to help me, only that I knew no fellow-creature was near enough to catch my wild summons. (V159)

Inside an atmospheric and psychological storm, a mysterious concoction and water imagery return to reflect the recurrent reverberation of her past trauma: the symbolical shipwreck. This excerpt of nightmarish iconography with 
inexplicable hallucinations, chaos, Gothic darkness, physical threats from an unknown tormentor, would be the euphemistic "cosmetics" to undercover a taboo, namely suicide, because such an action could not be publicly revealed during the $19^{\text {th }}$ century. Its social and theological dogmas stigmatised voluntary death as sinful and criminal, and not even Brontë would dare to approve or unravel this transgression to the reader. Therefore, reality could be distorted by fantasy, disclosure by ellipsis in this novel's chapter. The author would reproduce the same impenetrable strategy to veil and unveil the primitive trauma and its aftermath: self-destruction. Herman states that harrowing memories lack verbal narrative and context, but they are rather encoded as fragmentary images and vivid bodily sensations (38), which textually predominate in this and other acts of retrospection found in Villette to insinuate unutterable life experiences. Under this assumption, Lucy's suicide attempt could be clinically typified as melancholic according to Victorian standards, characterised by unendurable sadness and pain, but it could also aim to call the attention to her careless entourage. In any case, this episode would epitomise the fatal convergence of the three post-traumatic stress disorders, in terms of the heroine's helplessness, her expectation of mortal danger, and the recurrence of menacing water in her nightmares. Alone when she recovers her consciousness next day, she turns death into a dear anthropomorphic being to refuse admitting any guilt within herself:

Methought the well-loved dead, who had love me well in life, met me elsewhere, alienated: galled was my inmost spirit with an unutterable sense of despair about the future. Motive there was none why I should try to recover or wish to live; and yet quite unendurable was the pitiless and haughty voice in which Death challenged me to engage his unknown terrors. ( $V_{160}$, emphasis in original)

Lucy does not call a doctor for help, because she is a silent sufferer or she senses that she has no physical sickness, but a mental pathology with somatic symptoms, including suicidal raptures. Instead, she turns to religion ${ }^{12}$ for confession, but she finds no solace in Catholic Père Silas. She faints and is rescued by Dr John who takes her to his mother's household, Mrs. Bretton, who now coincidentally lives in Villette's. When she wakes up, she regrets not having died, which suggests that the acute detachment of her body from her newly-regained mental activity still persists: "I know she [her soul] re-entered her prison with pain, with reluctance, with a moan and a long shiver. The 
divorced mates, Spirit and Substance, were hard to re-unite: they greeted each other, not in an embrace, but a racking sort of struggle" (V 165). Lucy's body/ mind slowly recovers in the homely atmosphere of her beloved godmother. Her nightmares with gales and furious oceans do not entirely disappear, but the physical threat of drowning is mitigated by "coastal caves", which epitomise the human warmth at the Brettons, against her previous disorder of hyperarousal. Yet, she does not surrender to Dr John's clinical observation to diagnose her etiology, based on his suppositions of a former traumatic event and its recent sequel: the suicide attempt. The heroine does not confide in medical discourses to alleviate her pain, nor to cure her malady. In fact, she is stubbornly evasive during her physician's questioning: "I cannot put the case into words, but, my days and nights were grown intolerable; a cruel sensation of desolation pained by mind: a pain that $[\ldots]$ killed me" (V 185). She only acknowledges that she did "nothing wrong" (V185), when Dr John informs her that Père Silas told that she had committed "awful crimes" ( $V$ 184), although the priest did not reveal its nature because of the confessional secret. Again, narrative ellipsis invites us to wonder if these mortal sins refer to her aching experience from a remote past untold to the reader (where the protagonist was probably the victim), or other embarrassing episodes from a nearer time: her recent suicide attempt (where she was the perpetrator). Brontë's guerrilla of secrecy eventually succeeds: all ordeals of her creature are inferred, but they still remain vague, unspoken and non-investigated. Our understanding of Lucy's ailment is, thus, restricted to Dr John's diagnosis: "nervous fever", which she later echoes: "I [...] suffered a good deal, especially in the mind" ( $V 180)$. The author was probably indoctrinated in Victorian clinical discourses and she points to hysteria as Lucy's etiology. Moreover, this does not contradict the doctor's and the heroine's verdict, expressed in (pseudo)medical terms. Herman recalls that, traditionally, this pathology ${ }^{14}$ defines a strange disease with incoherent symptoms specific to women and originating in the uterus, or the scientific metaphor for anything than men found mysterious and unmanageable in the opposite sex (10). Even Freud stated that this condition that produced unbearable emotional reactions and altered states of consciousness was caused by psychological traumas (12). Apart from this diagnosis of hysteria, Lucy only admits the body/mind disorder of starvation: "During the last nine days I had no solid food, and suffered from continual thirst $[. .$.$] I experienced a craving for nourishment: an inward$ faintness" (VI 172). Her goal might be to divert her physician's attention - and her reader's - from her trauma and its severest somatisation: voluntary death. 
In any case, her obstinacy leads the physician to abandon his exploratory quest and prescribe her the therapy of joyful company, including himself.

Back to the boarding school, Lucy's infatuation with her new friend Dr John nourishes her heart "upon the verge of famine" (268). Nevertheless, she is soon confronted with a new intrusive replica of her primitive trauma: unrequited love, because this young man courts other ladies: Ginevra and Paulina. The heroine respects a traditional Victorian norm: a woman cannot articulate her romantic feelings. Disclosed to the reader this time, her "selfmedication" to conceal the outer symptoms of lovesickness will be to call the spirit of a dead nun mysteriously buried in the school, because she cannot communicate with the living. Villette's society can only offer her the modus vivendi of a spinster, characterised by self-denial, chastity and silence. In mute telepathy, the heroine perceives that she resembles that nun, because they are both socially invisible and bodiless ${ }^{15}$. In fact, this metaphor symptomatises her psychological disruption and her cry against male injustice and the monastic life prescribed to her (Gilbert and Gubar 425-426). When Lucy confesses to John that she witnessed ghost apparitions, he diagnoses that these are visual illusions provoked by her mental distress. He is right, but he fails to detect its plausible cause: this spirit would incarnate Lucy's thwarted expectations of romance with him. Anyhow, this confirms that she means a clinical case for this physician, not a friend.

Lucy's anorexia nervosa consisting of starvation and extreme thinness persists. It remains as her only proven psychosomatic disorder, now possibly correlated to sexual frustration since her re-acquaintance with John. Nevertheless, she does not only punish her own waning anatomy, or the bourgeois ideal of female slenderness, but she also criminalises other models of feminine silhouette and behaviour in Villette, based on flesh, health or gluttony, that she associates with promiscuity, Catholicism and lower classes. Victorian symbolism reflects the social standards that equate the consumption of meat and body fat with sexual appetite (Krugovoy-Silver 105). In line with this assumption, Lucy even extends the gastric disgust of her anorexia and the compulsory chastity to be expected from an unwed woman like her, to her prejudices against the abundant carnality and pernicious sexuality of the odalisque Cleopatra when she contemplates its canvas at Villette's Museum: "She was $[\ldots]$ well fed: very much butcher's meat $[. .$.$] must she have consumed$ to attain that breadth and height [...] She ought likewise to have worn decent garments, a gown covering her properly" (V199-200). The nausea produced by this sturdy, erotic image, which reinforces the sexual dimension of her 
eating disorder, can be added to Lucy's clearest symptom of anorexia: her intestinal reject of animal flesh. This is evident when, for instance, she refuses to eat some mutton that a school maid wanted to prepare for her: "She [...] would have been delighted to cook me côtelettes de mouton, if I could have eaten them" (V183).

Older and less attractive than John, Monsieur Paul Emanuel, the prestigious professor of literature at his cousin Madame Beck's, becomes Lucy's friend and mentor. Although Brontë foreshadows that he will not ultimately satiate her creature's hunger for love, she turns him into a pseudo-physician, whose praxis treats the heroine's psychosomatic disorders. He soon diagnoses her malady of a mental - not an organic - etiology: "You are well habituated to be passed by as a shadow in Life's sunshine" (334), in contrast with Dr John's aprioristic medical impressions about her patient: "quiet [...] inoffensive as a shadow" (317), which render her self invisible. The professor proposes a therapy of socialisation to strengthen her immune system, as well as to placate her consumptive and suicidal impulses. In fact, psychiatrists argue that trauma recovery cannot occur in isolation, because solid human relations are needed (Herman 133). Thanks to Paul, Lucy overcomes her emotional alienation and starts enjoying life. Together, they share worldly pleasures, like eating gourmandises, group activities and excursions, theatrical performances or meeting new acquaintances. Moreover, she finally masters the French language, and she enjoys her job and more autonomy from Madame Beck's discipline. Narratively, the heroine had earlier travelled incognito throughout Brontë's novel, without exhibiting her bodily presence or claiming the leading role in her own autobiography. In contrast, she had depicted other characters and described events in their lives, as if she were an omniscient narrator only and wanted to erase her self-portrait of wretchedness. But the course of the novel experiments a pivotal twist when its author starts articulating Lucy's inner voice with verbal outspokenness and physical intensity. For instance, she vehemently responds to Paul's prejudices against women, Protestants and British people. She also defends John from Ginevra's spitefulness, when he rejects her and chooses to court her cousin Paulina. Then, she acknowledges: "my outraged sense of justice at last and suddenly caught fire. An explosion ensued: for $I$ could be passionate, too" (V 321, emphasis in original). When Ginevra asks the heroine with impertinence: "Who are you, Miss Snowe?" ( $V$ 307), "are you anybody?" (V309, emphasis in original), she replies to her as an empowered phoenix: "I am a rising character: once an old lady's companion, 
then a nursery-governess, now a school-teacher" (V 309). Although Lucy gradually asserts her public self, she is still reluctant to unveil her mystery and true inner identity as a victim of trauma and its replicas of not lesser ferocity.

Increasingly nourished by affection and food, the heroine's body (in)voluntarily responds to emotions. Her devotion to Paul grows when he reveals his tragic love of youth ${ }^{16}$. Despite this sign of trust and communication between them, she does not reciprocate any confessions of trauma or its sequelae, at least, this is not narratively proven. Inwardly, she does not envision becoming his spouse: "I was willing to be his sister, on condition that he did not invite me to fill that relation to some future wife of his" ( $V 409)$. But outwardly, her body speaks through tears when she discovers that Paul must leave Villette for years because of a family engagement overseas. Her psychological recovery, enhanced by feelings, is now in jeopardy. Lucy's slender silhouette is eclipsed by the corpulent Madame Beck who, driven by obscure plans ${ }^{17}$, sedates her to hinder the last meeting of the couple before her cousin's departure for the West Indies. Paradoxically, this drug awakens Lucy's senses and unleashes her rage. Previously calm and silent, she now verbally somatises her mental pain and physical desire of togetherness: "Pierced deeper than I could endure [...] I cried - 'My heart will break'. What I felt seemed literal heart-break" ( $V 481)$, when her employer steals the last chance for love avowal. Beyond muteness, these illustrations of psychological amputation and, later, oral intelligibility are a part of a wide spectrum of emotions from exultation to anger, which she now effectively utters. Finally reunited, Paul announces to Lucy the life-project that he has prepared for her during his absence. As a "therapist", he believes that professional activity and business entrepreneurship are the effective antidotes to cure the heroine's ailments: "You shall employ yourself while I am away $[\ldots]$ You shall mind your health and happiness for my sake" $\left(V_{4} 87\right)$. With that purpose, he rented and refurbished a school to be managed by her, so that she becomes economically independent from Madame Beck ${ }^{18}$. During this first - but last - romantic rendez-vous with promises of marriage deferred to an uncertain future, Lucy also externalises the joyful contours of her soul: "I lifted my happy eyes: they were happy now, or they would have been no interpreters of my heart" ( $V_{4} 83$, emphasis in original). Although she grieves because of his departure, she now shows evidence of mental healing. She feels: "not desperate, nor yet desolate; not friendless; not hopeless, not sick of life, and seeking death" ( $\left.V_{482}\right)$. Yet, it remains narratively unknown whether the 
benign effect of this dual panacea - love and autonomous employment - will be transient or enduring in her body/mind, because her primal trauma is still a veiled taboo, ungovernable even for Paul.

Victorian novels enforce marriage on women. Charlotte's heroines in fane Eyre and Shirley - thin, virtuous and middle-class women like Lucy - eventually become loving wives after secular pilgrimages plagued with harsh trials. Moreover, Patrick Brontë wanted his daughter to create a happy-end for her latest fiction (Gaskell 414). Yet, her disobedience against her father's wishes and $19^{\text {th }}$-century literary conventions won. As a more mature author then, she decided that the professor had to die to conclude Villette if she wanted to subvert the patriarchal enforcement of romanticism prescribed to Victorian women writers and the compulsory female obedience to male authority. Paul stimulates her heroine's physical/psychical cure, but he is not allowed to witness her success as a school director. Only his absence guarantees the self-sufficiency of a newly-coined "female bachelorhood", achieved thanks to the remedy of professional self-fulfilment. In fact, this original variant would release her body/mind from both: the nausea of sexual wifehood and the perpetuation of the psychosomatic disorders in a presumptively frigid spinsterhood. After three years abroad, the professor is about to join his fiancée in Villette. However, a God-like Brontë confiscates water, the pervasive textual medium of trauma and its self-destructive reproductions, which previously terrorised Lucy through nightmares of shipwreck and drowning. Now the author uses her Neptunian wrath to "murder" the Catholic hero, who could have interrupted her creature's enriching professional career and urged her to domesticity. Paul seems to perish during a non-metaphorical Atlantic storm in a true sea-voyage. Nevertheless, the novel does not report if he dies or returns alive to European coasts.

The novelist declines her narrative authorship and says farewell to the reader before concluding Villette. She encourages Lucy to harbour hopes about an unlikely rescue to differ her confrontation with the past ordeal and its new replica: death. Although it is never final, Herman declares that the three stages to successfully heal from trauma are to establish safety, remembrance/ mourning, and the reconnection with ordinary life (155). Lucy briefly describes her last three years as the happiest ones in her life, unscathed and unmolested in her permanent residence, prosperous business and social activities. The first and third phases of recovery are likely to have been accomplished because there is no evidence of physical threats or unwanted isolation. Consequently, the harmful side-effects of constriction and hyperarousal would diminish. Yet 
the reader may have a dilemma after this new tragedy. Lucy's health could be fully restored, she would have learnt to endure adversity with stoicism and the symptoms of intrusion would have now been mitigated. Likewise, she could relapse because her primitive trauma could be cyclically repeated. It will not be until she writes her memoirs in more mature years, that she fulfils the missing phase of her recovery - avowal - to confirm the recession of her psychosomatic disorders. However, the recognition of trauma is also central to its treatment (Herman 127). Lucy does not seem to admit it. Her final words as an old lady, who completes the account of selected past recollections reflect her verbal reluctance to declare her status as a victim and the complexity of her prognosis: "Few things shook me now; few things had importance to vex, intimidate, or depress me: most things pleased - mere trifles had a charm" ( $V$ 494). Indeterminate between healing and recidivism, neither does she ultimately confess the nature of her trauma nor its subsequent reproductions. Despite this textual evidence, there are no traces of mourning Paul for years and dreadful nightmares or mental anxiety do not seem to return to her life. The novel's constant elliptical quality to feed its heroine's secrecy now allies with its final touch of unreliability: the embellishment of a "placid (non)happy-end".

Lucy Snowe's private crisis aftermath in the past, departing from an obscure ordeal in more remote times, provides the backbone of Villette. This fiction becomes the prose redaction of the psychological voyage into the blurred, altered consciousness of Brontë's most autobiographical heroine, which challenges critical interpretations based exclusively on the author's depression after the tragic deaths of her sisters. Through the humanistic lens of literature, she applies a paramedical praxis of heterodoxy in order to explore the symptomology of psychosomatic disorders, affecting the female body/mind. But prudishly, she declines to diagnose its etiology to protect her creature's intimacy and not to reveal the origin of her unspeakable trauma, because the public disclosure of devious, unlawful taboos were not only unintelligible or unassimilable to her, but they would have also violated religious and social dogmas, which enforced female silence, even as a victim. Besides, we should not forget that, after Fane Eyre, Charlotte Brontë was a best-selling author, subject to the tyranny of her devotees' reading expectations. Therefore, she only dares to suggest that it is unnecessary to dissipate the nebula of (un)conscious memories, nor to explicitly narrate the recollections of harrowing life episodes so as to overcome them. Instead, her sympathetic perspective shares with the reader the burden of human pain, glimpses of resilience and 
the small victories in the daily life of a vulnerable woman to, progressively, eradicate harmful nervous disorders. From unlovability, retreat, hopelessness, muteness, hunger and body detachment, Lucy ultimately vindicates her voice and body/mind visibility thanks to a gratifying professional activity. Occupational self-realisation and economic independence - not depending solely on the love of a man or marriage - may be, thus, the only effective therapy to gain control over sensory stimuli, social exposure, cognition and emotions, although she never unravels her life-long enigma. This would be the author's surreptitious, modest proposal of revisionism in the Victorian treatment of female nervous maladies, without overtly accusing physicians of being subservient to misogynist patriarchal discourses or doubting that their diagnosis of hysteria is beneficial to understand her heroine's nervous disorders. But now and then, Brontë's noncompliance with the readers' literary expectations of satisfactory disentanglement should not be predictive of the possible deterioration of Lucy's soma/psyche when Villette ends. The prognosis of her trauma recovery should not be discarded only under the assumption that the former ordeal is never named or explained. The author might believe that contemporary literary and medical discourses cannot be reconciled yet, so any diagnosis to be delivered would be tentative for women writers like her, and textually misleading due to their mandatory indoctrination in a maledominated culture. In short, she would embrace that words fail to express and explain the body/mind workings, whereas $19^{\text {th }}$-century science is still biased and subjugates women thanks to its alliance with Victorian gender prejudices. Without any clear enlightenment for the reader, Brontë's psychological realism of literary/clinical irreverence, as well as her peripheral analysis of Lucy's psychosomatic disorders, omit confronting the core of her creature's trauma. Instead, she trusts a strategy of secrecy to preserve her privacy and weave deeper tissues of suffering and embarrassment away from public scrutiny, similar to Christina Rossetti's cryptic verses of jolliness and unease.

\section{Notes}

1. Freud's psychoanalysis acknowledges that psychosomatic disorders are linked to the unconscious. Furst highlights that this school uses the term "conversion" to refer to the process whereby psychic excitation is transmuted into somatic symptoms, resulting in hysteria (32).

2. The ${ }^{185^{1}}$ population census in Great Britain revealed that there were hundreds of thousands of more women than men, so these women were "redundant" (Ingham 129). 
3. Between 1848 and 1849 , all her siblings died of tuberculosis or respiratory diseases.

4. Charlotte Brontë's first literary analysis of female pathologies is found in Fane Eyre's Bertha Mason, the Creole first wife of Rochester, declared mad and incarcerated in Thornfield.

5. Villette will be hereafter referred to by $V$, followed by the page number.

6. This is a rhetorical device wherein the writer brings up a subject by denying that it should be brought up with a clear subversive purpose. Brontë uses paralepsis to distance her heroine from undesirable events, while she also claims the reader's careful attention to their occurrence inside and outside the novel.

7. Fictional name of Brussels, where Charlotte stayed twice.

8. Brontë's experiences as a governess and a teacher account for her understanding of the ambiguous status of these occupations of middle-class young women, sometimes resulting in physical and mental disorders.

9. Anorexia nervosa is the significant loss of human weight derived from an extreme control of food intake, a fear to gain weight, a distortion of the body image and, in women, a hormonal disequilibrium or amenorrhea.

10. Brontë already explored anorexia nervosa in her previous novel Shirley (1849). There, Caroline Helstone suffered from such a pathology due to unrequited love and social isolation.

11. Many biographical sources indicate that Charlotte and Emily Brontë engaged in draconian eating habits and starvation diets, which could be today categorised as anorexia nervosa.

12. Villette also dramatises the absence of understanding between English Protestantism Lucy's faith - and Catholicism in a Francophone city.

13. A clue to Lucy's unreliability as a narrator is that she purposely hides that she knows Dr John since they were children. In contrast, her godmother's son does not recognise her, although he is the visiting doctor at Madame Beck's school in Villette. She falls in love with him. Nonetheless, it is an undisclosed enigma in the novel why Mrs. Bretton disappeared from the heroine's life in England during her adolescence.

14. In Trauma and Recovery, Judith Herman analyses hysteria (an archetypical female psychological disorder) in the $19^{\text {th }}$ century, together with shell-shock or combat neurosis and domestic/gender violence.

15. Ginevra later confesses to Lucy that her future husband disguised himself in a nun's habit to pretend to be a ghost that visited her at night at her school without being discovered. This is also intended to mock the heroine.

16. Years before, the penniless but ambitious Monsieur Paul was separated from his fiancée Justine Marie, due to family pressures and their different social rank. She was, then, confined to a convent, where she died. After achieving professional success, moral duty forced this professor to guarantee the well-being of Madame Walvarens: Justine's impoverished grandmother in later times.

17. Aware of Monsieur Paul's growing feelings for Lucy, Madame Beck, Père Silas and Madame Walvarens planned together to send away the professor to manage the neglected businesses of the latter in the West Indies, so as to separate him from the heroine: a rival woman, a Protestant and a foreigner.

18. Villette illustrates Charlotte Brontë's entrepreneurial project with her sisters: to found a school for girls, which was finally abandoned due to their deaths and her later career as a successful novelist. 


\section{Works Cited}

Brontë, Charlotte. Villette. Oxford: OUP, 2008. Print.

Carlisle, Janice. "The Face in the Mirror: Villette and the Conventions of Autobiography." English Literary History 46(2) 1979: 262-289. Print.

Caruth, Cathy. Unclaimed Experience: Trauma, Narrative, and History. Baltimore: John Hopkins UP, 2010. Print.

Foucault, Michel. The History of Sexuality. Vol. I. New York: Pantheon, 1976. Print.

Furst, Lilian. Idioms of Distress: Psychosomatic Disorders in Medical and Imaginative Literature. Albany: State University of New York, 2003. Print.

Gaskell, Elizabeth. The Life of Charlotte Brontë. Oxford: OUP, 2006. Print.

Gilbert, Sandra \& Susan Gubar. The Madwoman in the Attic. New Haven: Yale UP, 2000. Print.

Haller, Elizabeth. "Perception and the Suppression of Identity in Villette". Brontë Studies 35(2) 2010: 149-159. Print.

Herman, Judith. Trauma and Recovery. New York: Basic, 1997. Print.

Ingham, Patricia. The Brontës. Oxford: OUP, 2006. Print.

Kradin, Richard "Psychosomatic Disorders: the Canalization of Mind into Matter". Fournal of Analytical Psychology 56(1) 2011: 37-55. Print.

Krugovoy-Silver, Anna. Victorian Literature and the Anorexic Body. Cambridge: CUP, 2004. Print.

Malson, Helen. The Thin Woman: Feminism, Post-structuralism and the Social Psychology of Anorexia Nervosa. London: Routledge, 1998. Print.

Orbach, Israel. "The Body-Mind of the Suicidal Person." Cognition and Suicide: Theory, Research, and Therapy. Ed. Thomas Ellis. Washington: American Psychological Association, 2006: 193-214. Print.

Rossetti, Christina. Poems and Prose. Oxford: OUP, 2008. Print.

Showalter, Elaine. The Female Malady. London: Virago, 1985. Print.

Tofighi, Bhaman. "A Study of the Relationship between Stress and Psychosomatic Disorders." International Proceedings of Economics Development and Research 44(1) 2012: 124-127. Print.

Vrettos, Athena. "From Neurosis to Narrative: The Private Life of the Nerves in Villette and Daniel Deronda." Victorian Studies 33(4) 1990: 551-579. Print.

FRANCISCO JOSÉ CORTÉS VIECO (Ph.D. \& M.A. in Literary Studies, Universidad Complutense de Madrid, PhD Thesis Award 2012-2013) currently teaches British and North-American Literature at Universidad Complutense 
de Madrid, primarily courses on $19^{\text {th }}$ and $20^{\text {th }}$-century Literature. He has previously taught English at Universidad Autónoma de Madrid, and he was enrolled in University of Oxford/Exeter College summer courses in 2008. $\mathrm{He}$ is also a member of the Spanish research group "Women's Studies in the English-Speaking Countries", and he is interested in the Victorian novel and women writers' poetry \& autobiography, particularly their interrelations with clinical, psychological, gender and cultural discourses. Apart from other publications in journals, he is the author of the translation (in Spanish) and the critical edition of Emily Brontë's poetry: El Romancero de Emily Brontë: Antología Épica y Lírica (2014).

francort@filol.ucm.es 